Таким образом, в башкирской языковой картине мира образ женщины воплощается во многих фольклорных и художественных материалах, отражающих такие качества башкирской женщины, как мудрость, уважительное и заботливое отношение к мужу, детям и другим членам семьи, хозяйственность. В целом отмечено преобладание положительных качеств над негативными, что свидетельствует об уважении к женщине в культуре башкирского народа.

1. Бабушкин А.П. Типы концептов в лексико-фразеологической семантике языка, их личностная и национальная специфика. Дис. ... д-ра филол. наук. Воронеж, 1997. 330 с.

2. Башкорт халык ижады. Мәкәлдәр һәм әйтемдәр. Өфө: Башкортостан китап нәшриәте, 1980. 472 бит.

3. Башкорт халык ижады. 5-се том. Тарихи кобайырзар, хикәйәттәр (иртәктәр). Өфө: Китап, 2000. 392 бит.

4. Бухарова Г. Х. Башкирский народный эпос «Урал-Батыр»: когнитивно-дискурсивный и концептуальный анализ: автореф. дис. ... д-ра филол. наук. Уфа, 2009. 52 с.

5. Колшанский Г.В. Объективная картина мира в познании языка. М.: Наука, 1990.

6. Кубрякова Е.С. Язык и знание: На пути получения знаний о языке: Части речи с когнитивной точки зрения. Роль языка в познании мира. М.: Языки славянской культуры, 2004.

7. Лихачев Д.С. Концептосфера русского языка // Известия РАН. Сер. лит. и яз. М., 1993. Т. 52 , № 1. C. 3-9.

8. Хусаинова Г. Р. Идеал женской красоты у башкир (на материале фольклора) // Мать и дитя у народов Башкортостана: материалы межрегиональной научно-практической конференции. Уфа, 2001. С. 253-255.

9. Әхтәмов М.Х. Әсә. Мәкәлдәр һәм әйтемдәр: һүзлек. Өфө: Китап, 2002. 160 бит.

\title{
Гейдарова Э.А. \\ Роль метафоры в формировании языковой картины мира диалектоносителей
}

Бакинский государственный университет (Азербайджан, Баку)

doi: 10.18411/lj-05-2021-268

\section{Аннотация}

Рассматриваются метафорические номинации в русском островном говоре Азербайджана. В результате проведенного исследования выявлено 28 метафор. В рамках двух лексико-тематических групп представлены биоморфные (6), предметные (13), социальные (7), геоморфные (1) и цветовые (1) метафоры. Исследование показало, что для создания метафор активнее всего используется предметная сфера.

Ключевые слова: лингвокультурология, языковая картина мира, русский островной говор, лексико-тематические группы слов, метафорические номинации

\section{Abstract}

Considers metaphorical nominations in the Russian island dialect of Azerbaijan. As a result of the research 28 metaphors were identified. Within the framework of two lexicalthematic groups, biomorphic (6), subject (13), social (7), geomorphic (1) and color (1) metaphors are presented. The research has shown that the subject area is most actively used to create metaphors.

Keywords: linguoculturology, a linguistic picture of the world, the Russian insular dialect, lexico-thematic word groups, metaphorical nominations

«В последние годы возросло внимание лингвистов к проблемам развития и функционирования народных говоров» [4, с. 20], что во многом обусловлено осознанием значения говоров как хранителей своеобразия национальной языковой картины мира. При этом необходимым представляется исследование не только 
материнских диалектов, но и говоров, находящихся в отрыве от метрополии. Функционирующие в изоляции говоры сохраняют и отражают специфическое видение мира их носителей. Ибо «большим культурологическим потенциалом обладает не только литературный язык, но и диалекты, изучение которых расширяет возможности страноведческих исследований». [1, с. 51] Именно поэтому диалект может и должен стать объектом лингвокультурологического изучения.

«Народный язык, говоры, народные обряды, представления и вся народная культура вкупе с элементами входящей в нее материальной культуры представляет собой единое целое». [8, с. 21] По мнению Н.И. Толстого, диалект - не исключительно лингвистическая территориальная единица, а одновременно и этнографическая. «Народно-речевая основа, воплощенная в диалектах, вносит такой вклад в русскую речевую культуру, который затрагивает самые принципы видения мира». [6, с. 3]

В последние годы метафора, играющая важную роль в формировании языковой картины мира, стала рассматриваться как средство номинации. Учитывая это, основной целью настоящего исследования было изучение лексического состава русского островного говора Азербайджана и выявление метафор в тематических группах «Одежда и ее составляющие, названия головных уборов, украшения, обувь», «Кухонная утварь и предметы домашнего обихода».

Материалом исследования послужил «Лексикон русского островного говора Азербайджана», а также видео и аудио записи встречи с пресвитером села Ивановка Исмаиллинского района Азербайджана Прокофьевым Василием Терентьевичем (19362020).

Метафоры в языке носителей русского островного говора Азербайджана начала изучать Г.Д. Удалых. В статье «Языковая картина мира молокан-старообрядцев Азербайджана» она подробно исследовала сферу «Растительный и животный мир». В рамках же представленных лексико-тематических групп метафорические номинации анализируются впервые.

\section{Кухонная утварь и предметы домашнего обихода}

В исследуемую группу входит «304 примера, 123 из которых относятся к посуде и кухонной утвари, а 181 - к предметам домашнего обихода.». [2, с. 38]

В данной группе отмечены слова, обозначающие разновидности одного и того же предмета. К ним относятся:

"кувшин" - барда́к, би́лка, гарахве́н, гле́чик, джарда́к, джулда́к, долгоше́йник, кагла́ , кали́нка, куп и купа́, макúтра, махо́тка, сары́нч (13 слов);

"кадка; посуда, в которой замешивается тесто" - дежа́, дёжа́ и дешня́, жёлоб, квашня́, кестя́ник, лото́к, чана́к (7 слов);

"сковорода" - жаре́льник, пеку́шка; жаро́вник, жаро́нник и жаро́вня, ра́мка, ско́врода; чапано́к, ча́пельник, ча́пальник, ча́пленик, ча́пелька и чапле́йка (10слов);

"половник" - кашы́г, ковш, коре́ц, ополо́вник, черпа́лка (5 слов) и другие.

В рамках группы метафорический перенос осуществлен, в основном, по модели предмет $\rightarrow$ предмет.

Кор єmо "большая деревянная чашка" [3, с. 18]. В литературном языке данное слово обозначает предмет хозяйственного обихода, сделанный из широкого бревна, расколотого пополам и выдолбленного с плоской стороны. Используется для корма скота, различных домашних надобностей, например стирки белья. Метафоризация актуализирует размеры предмета и возможность вдоволь напоить.

Рámкa "сковорода, на которой выпекают хлеб" [3, с. 19]. Метафорическая номинация развилась на основе ассоциаций с шаблоном, определенными рамками, благодаря которым выпекают одинаковый по форме хлеб.

Подобных примеров метафоризации достаточно много: бро́шка "булавка", mpyбá "стекло для лампы (керосиновой)", махо́mка "небольшой глиняный горшок без 
ручки", занаве́ска "фартук без нагрудника, передник", па́лка "швабра", трПика "полотенце для рук", ча́шка "глубокая глиняная миска для обеда" и др.

Социальная метафора представлена такими примерами, как мясни́к "горшок, в котором варят мясо", жси́лик "стакан". Хотя этимология последней номинации неясная.

В нескольких примерах отражена антропоморфная метафора. Ее источником является «человек, анатомия и физиология человеческого тела, а также отдельные его части, органы и совершаемые им действия» [7, с. 8]: $\boldsymbol{n}$ Птка "замочная петля на двери", долгору́к "деревянный ковш с длинной ручкой", долгоше́йник "кувшин с длинным горлом", набе́дерник "черпак", нало́бник "гребешок".

В рамках группы отмечена зооморфная метафора: рогáı "приспособление для подхватывания чугуна, горшка из печки, ухват". Метафорическая номинация образована на сходстве рабочей части ухвата с рогами животного.

Цветовая метафора представлена примером желт Пнка "деревянная ложка с золотистой лаковой поверхностью".

Таким образом, в качестве источников метафоризации выявлены следующие метафорические номинации: предметные - 9, социальные - 2, биоморфные - 6 (антропоморфные - 5, зооморфные - 1), цветовые - 1 .

Одежда и ее составляющие, названия головных уборов, украшения, обувь

В исследуемую группу входит 17 названий головных уборов, 13 наименований украшений, 124 слова, обозначающие одежду и ее составляющие, а подгруппа «Обувь» включает 34 слова.

Проведенный анализ показал, что в словарном составе островного говора можно отметить множество названий одного и того же предмета, в которых детализируется их вид. Например:

"бусы" - бисери́нки, вёрстки, жерёлки, ни́зки (4 слова);

"головной платок, косынка" - бежи́вка, голсти́на, коси́нка, мале́чка, подша́льник, полуша́лок (6 слов);

"кафтан" - азя́м и азём, архалу́к, зипєн, капта́н, трухкли́нка (5 слов);

"кофта" - ба́ска, бибе́шка, вяза́нка, дува́йка, е́шка, зуя́вка, казачки́, кира́ска, ко́хта, крата́йка, крутя́шка, ливо́к, ли́фчик, распу́шенка и распушо́нка, стану́шка (15 слов).

В тематической группе выявлены социальные метафоры, образованные от этнонимов: бедуи́н "широкая юбка", кабарди́нка - 1) старинный женский головной убор; 2) женская высокая четырёхугольная бархатная шапка.

Источником метафоризации может выступать название рода деятельности. Примерами такого переноса являются следующие номинации: манже́тница "женская рубашка с кружевной оборкой", ла́nотник "лапоть", ходоки́ - 1) самодельная мужская обувь из кожи; 2) башмаки; 3) тапочки, связанные из шерсти; 4) сапоги без голенищ; ботинки; 5) рабочие туфли (женские).

В тематической группе отмечена также геоморфная метафора: вилюшки "бисер": «Ма́m' майá в’uл'ýшк’u самá d’е́лълъ». [5, с. 71] В островном говоре употребляется также слово вилюшка (мн.ч. вилюшки) - "извилистая горная дорога, тропинка": «Пъдн'има́л'ис' пъ в 'ил'у́шкъм». [5, с. 70] Это небольшой географический объект, не имеющий своего названия. Возможно, причиной появления метафоры послужило сходство строчки, вышитой бисером, с извилистой тонкой тропинкой. Вышивание бисером популярно среди рукодельниц. Женщины часто расшивают бисером элементы одежды, рушники.

К предметным метафорам относятся, например: өше́йник "воротник", пала́тка "брюки", подста́вка - 1) нижняя часть женской рубашки; 2) нижняя самотканная юбка из холста с кружевами; корабли́ "обувь наподобие калош до щиколоток, калоши". Метафорический перенос осуществлен по модели предмет $\rightarrow$ предмет. Так, слово 
ошейник употребляется в значении "воротник" в силу того, что мужчины носят рубашку навыпуск, однако верхняя пуговица обязательно должна всегда оставаться застегнутой. Это вызывает ассоциацию с тугим ошейником.

Таким образом, в пределах группы представлены социальные (5), геоморфные (1) и предметные (4) метафоры.

Всего было выявлено 28 метафорических номинаций: предметные (13), социальные (7), биоморфные (6), геоморфные (1) и цветовые (1). В них отражаются результаты познания мира, которые предстают яркими россыпями в повседневной речи носителей говора. Исследование показало, что для создания метафор активнее всего используется предметная сфера.

Некоторые номинации в их прямом значении употреблялись не столь часто. Но, благодаря метафорическому переносу, они вошли в активный словарь диалектоносителей, например: бедуин, кабардинка.

Метафорические номинации в говоре схожи с красками, благодаря которым художник передает всю палитру окружающего мира.

1. Брысина Е.В. Диалект через призму лингвокультурологии. // Вестник Волгоградского государственного университета. Серия 2. Языкознание, 2012, №2 (16), с. 51-56.

2. Гейдарова Э.А. Языковой портрет русского островного говора Азербайджана. Москва: Университетская книга, 2017, 303 с.

3. Гейдарова Э.А. Лексическая система русского островного говора Азербайджана. Баку: AVROPA, 2015, 178 c.

4. Гейдарова Э.А. Особенности выражения категории рода в русском островном говоре Азербайджана. // Sciences of Europe. Praha, Czech Republic, 2021, № 67, c. 20-25.

5. Гулиева Л.Г., Гейдарова Э.А. Лексикон русского островного говора Азер-байджана. Баку: Авропа, 2014, 498 c.

6. Гольдин В.Е. Теоретические проблемы коммуникативной диалектологии. Автореферат диссертации доктора филологических наук. Саратов, 1997, 33 с.

7. Удалых Г.Д. Языковая картина мира молокан-старообрядцев Азербайджана. // Русский язык и литература в Азербайджане. Баку: БСУ, 2015, № 4, с. 4-9.

8. Толстой Н.И. Язык и народная духовная культура. Очерки по славянской мифологии и этнолингвистике. М.: Языки славянской культуры, 1995, 483 с.

\section{Демидова М.М. \\ К проблеме передачи категории диминутивности при переводе с русского на английский язык}

Брянский государственный технический университет

(Россия, Брянск)

doi: 10.18411/lj-05-2021-269

\section{Аннотация}

Статья посвящена вопросам перевода русской субстантивной лексики с уменьшительно-ласкательными суффиксами на английский язык. Исследование проводилось на богатом материале художественного произведения Л. Улицкой. В статье рассматривается понятие категории диминутивности в русском и английском языках, анализируются способы передачи суффиксов на английский язык.

Ключевые слова: диминутивность, перевод, уменьшительно-ласкательные суффиксы, существительные, русский язык, английский язык.

\section{Abstract}

The article is devoted to the translation of Russian substantive lexis with diminutive suffixes into English. The research was carried out on the rich material of L. Ulitskaya's 